\title{
Oral health in Brazil: the challenges for dental health care models*
}

\section{Sônia Cristina Lima Chaves}

Institute of Collective Health, School of Dentistry, Univ Federal da Bahia, Salvador, Bahia, Brazil.

\footnotetext{
* Paper presented at the "Oral Health Under an Integrality Perspective" International Symposium, held at the $17^{\text {th }}$ Congress of the Brazilian Association for Oral Health Promotion (ABOPREV), May 31 to June 2, 2012, Salvador, BA, Brazil.
}

Declaration of Interests: The author certifies that she has no commercial or associative interest that represents a conflict of interest in connection with the manuscript.

Corresponding Author:

Sônia Cristina Lima Chaves

E-mail:schaves@ufba.br

Submitted: Aug 11, 2012

Accepted for publication: Sep 21, 2012

Last revision: Oct 19, 2012
Abstract: This paper discusses adult oral health in Brazil according to three perspectives: 1) the available epidemiological evidence about the population's oral-health-related epidemiological situation, especially adults and the elderly population, in relation to two high prevalence oral injuries (dental caries and tooth loss), 2) the main health care models for dealing with this situation, by analyzing the related historical processes in order to reveal the likely social, political and epidemiological implications of the different models, and 3) lastly, the possible challenges to Brazilian dentistry or collective oral health in overcoming these obstacles. The main results of the study indicate that, from an epidemiological point of view, Brazil is undergoing a transition in dental caries and tooth loss, which is not yet reflected in the profile of the elderly, but which is tentatively evidenced in young adults. Tooth loss remains high. Certain aspects of society's economic and political superstructure have an important impact on oral health indicators and existing inequalities. Oral health care models have a relative importance and must not be neglected. Vestiges of ideological movements, like preventive medicine, may explain the current impasse in collective oral health practices, such as the preeminence of Finalized Treatment (FT) in clinics and of preventive care in schools fostered by community-based programs. It is therefore important to develop conceptual, theoretical reflections and to increase the objects of intervention, their purposes and their modus operandi. The practice of dentistry according to these alternative models is still being constructed. New studies related to the different formats of these new practices are recommended.

Descriptors: Dental Care; Health Policy; Tooth Loss; Adult; Comprehensive Dental Care.

\section{Introduction}

The social scourge represented by tooth loss among Brazilian adults is a topic explored in society beyond the natural interest of dentists. In Bahia, artist Bel Borba, known as the artist who most often portrays the relationship between the reality of his city and its people, recently exhibited a work of art with many "before and after" photographs of prosthetics in a number of edentulous adults; the catalogue's symbolic phrase was, "life took the teeth and the smile restored the soul."

Although this assertion may lead to a great many reflections and conclusions, current discussions about adult oral health in the national and 
international ${ }^{2-4}$ literature may indicate greater concern in relation to this age group, considering that a large portion of the scientific community working on health policies and the prevention of oral problems in the $20^{\text {th }}$ century focused on children and adolescents, and has had relative success. ${ }^{4,5}$ In the case of Brazil, efforts by the government and researchers to monitor this data constantly have yielded optimistic albeit cautious results, insofar as studies reveal that the strategies implemented in the young population did not automatically benefit adults.

The undoubted success of these efforts has already been evidenced in a large number of studies and from consultations with experts about the contribution of water fluoridation and the use of fluoride toothpaste in different oral contexts, together with mass access to toothbrushes and wide-scale coverage for families. The upshot has been a reduction in dental caries and some success in preventing the early signs of periodontal disease. ${ }^{5,7}$

In Brazil's most recent national survey, the average DMFT index (number of decayed, missing or filled teeth) for 12-year-olds was 2.1, 25\% less than the 2.8 figure recorded in 2003. It is worth noting that the first national survey of the DMFT in 12-year-olds in Brazil was conducted in 1986, when the index was 6.7. In the component relating to dental caries, the average fell from 1.7 to 1.2. The percentage of caries-free children $(\mathrm{DMFT}=0)$ rose from $31 \%$ in 2003 to $44 \%$ in $2010^{7}$ (Table 1 ).
It is also worth noting that the caries-free proportion of five-year-old children rose from $40.6 \%$ to $44 \%$. This shows a trend toward stability in the prevalence of dental caries in this group, although short of the WHO target for the year 2000, which was $50 \%$ caries-free. ${ }^{5}$ Furthermore, the proportion of the DMFT decayed component remains very high, suggesting limited or no access to curative dental treatment in primary health care. ${ }^{7}$

The targets for dental caries in the adult population are still far from being attained (Table 1). One of the probable explanations is that the strategies implemented for the Brazilian population in the 1990s, through fluoride toothpaste, expansion of water fluoridation and community-based prevention activities in the public health system for oral diseases, ${ }^{7,8}$ had little effect on the adult population, which did not receive the benefits that population aged about 20 years old received in the 1990s. Cury et al. ${ }^{9}$ called this process in Brazil the "90 factor" (from the 1990s), related to the organizational and political changes of the re-democratization process that occurred in the country during this period.

However, in recent decades, the WHO indicators for the adult population in Brazil have shown little progress. The DMFT for the 65-74 age range was 27.5 in 2010, whereas it was 27.9 in $2003 .^{7}$ The greatest improvement was found in the 35-44 age group, which had a DMFT of 20.1 in 2003 and of 17.2 in 2010 . There is no information available in

Table 1 - Comparison between the goals proposed by the World Health Organization / International Dental Federation (FDI) for the year 2000 in relation to dental caries, and the results of the Oral Health Brazil Project (Projeto SB Brasil), Brazil, 2003 and 2010 .

\begin{tabular}{|c|c|c|c|}
\hline Indicator by age group & WHO goals & Oral Health Brazil 2003 & Oral Health Brazil 2010 \\
\hline$\%$ of caries-free children (DMFT $=0$ ) at five years old & $50.0 \%$ & $40.6 \%$ & $44 \%$ \\
\hline DMFT Index at 12 years old & $\mathrm{DMFT} \leq 3$ & $\mathrm{DMFT}=2.78$ & $\mathrm{DMFT}=2.1$ \\
\hline $\begin{array}{l}\% \text { of individuals with all their teeth at } 18 \text { years old } \\
(M=0)^{*}\end{array}$ & $80.0 \%$ & $\begin{array}{c}M=0: 55.1 \% \\
\text { DMFT } 15-19 \text { years }=6.2\end{array}$ & $\begin{array}{c}\text { DMFT }=0: 23.9 \% \\
\text { DMFT } 15-19 \text { years }=4.7\end{array}$ \\
\hline $\begin{array}{l}\% \text { of individuals with } 20 \text { or more teeth at } 35 \text { to } 44 \text { years } \\
\text { old }(M \leq 12)^{*}\end{array}$ & $75.0 \%$ & $\begin{array}{l}\% 20+\text { teeth }=53.96 \% \\
\text { DMFT }=20.1\end{array}$ & $\mathrm{DMFT}=17.2$ \\
\hline $\begin{array}{l}\% \text { of individuals with } 20 \text { or more teeth at } 65 \text { to } 74 \text { years } \\
\text { old }(M \leq 12)^{*}\end{array}$ & $50.0 \%$ & $\begin{array}{c}\% 20+\text { teeth }=10.23 \% \\
\text { DMFT }=27.8 \\
24 \% \text { require prosthetics in } \\
\text { both dental arches }\end{array}$ & $\begin{array}{c}\text { DMFT }=27.5 \\
23 \% \text { require prosthetics in } \\
\text { both dental arches }\end{array}$ \\
\hline
\end{tabular}

Sources: ${ }^{4-7} .{ }^{*}$ There is no information in the SB 2010 report. 
the final SB 2010 report for some goals (Table 1).

One could posit that the improvements reported in the epidemiological surveys of 1986, 2003 and 2010 are the result of improvements at school age, given that the 1986 school population has now reached young adulthood, and that we can, therefore, expect such improvements to be reflected in lower DMFT values, for example.

Studies reveal that the situation is different in other parts of the world, particularly in European countries, which have had DMFTs between 13.4 and 20.8 for the 35-44 year-olds, ever since the end of the last century (the $20^{\text {th }}$ century). There is a trend toward a fall in tooth loss. ${ }^{2,10,11}$ However, information in most countries about current national estimates for dental caries or tooth loss in adults is limited, due to problems related to the frequency of studies, the indicators and methodologies used for diagnostic criteria, sample size and data presentation. ${ }^{2,10}$ Furthermore, it is known that edentulism is in decline, and this has also been investigated by the dental market, given the likely implications for specialties such as implantology. ${ }^{2,12}$ We should remember that demographic trends suggest a rise in the aging population, due to a reduction in birth rates and an increase in life expectancy, related to better management of chronic non-communicable diseases (NCDs). The United Nations estimates that the proportion of the world population over 60 years old will rise from $10 \%$ in 2000 to $30 \%$ in $2150 .^{2}$

It is noteworthy that, despite the great scientific production of epidemiology-based studies about the relationship between the social determinants of health and oral health, ${ }^{13-16}$ this area has been little explored from the perspective of reasons or theories able to explain oral health inequalities. ${ }^{17,18}$ Furthermore, there is a significant gap in evidence regarding the implementation of oral-health related interventions incorporating the principle of equity, in other words, the notion that it is necessary to intervene unequally where inequalities exist.

A review study about the effect of public health interventions on principal health issues indicates that oral health is one area which has produced the least results. ${ }^{19}$

Brazilian studies addressing or mapping inter- ventions or models for oral health care ${ }^{20-23}$ have not included the construction of a theoretical-conceptual framework for the social or social-dentistry field in dental practice.

Accordingly, and in light of the work by Paim and Teixeira, ${ }^{24}$ this study aims to describe and analyze different care models as interventions to confront both the aforementioned needs and oral health issues, by analyzing work processes in health ${ }^{25}$ and considering the implications of this perspective in organizing dental services.

With this in mind, it is important to make a critical review of national and international scientific productions related to oral health care interventions and models from the perspective of work processes in health. ${ }^{25}$

\section{Health care models, care models and needs}

In our context, care models are understood as combinations of technology (both structured and non-structured, such as knowledge) to solve problems and meet individual and collective demands. They include ways of arranging the technical-scientific means to intervene in determinants, risks and health-related injuries. According to Paim and Teixeira, ${ }^{24}$ it is the "contents" of health systems, the practices, in other words, the working processes, that produce different types of care.

In other words, working processes in health refer to the way in which health activities are produced, the care, per se. The principal components of this analysis are the object of the work, the instruments, the resources and products or results of this work, as well as the producing agents. It also worth noting that these elements need to be examined jointly, since they may shape specific work processes, but only through reciprocal relationships. ${ }^{25}$

The object of the work is the target of change, represented by what Mendes-Gonçalves ${ }^{25}$ calls health "gaps," understood as health needs. It is not enough to simply talk of "needs," since there is a difference between essential needs and those aspects which are perceived as needs.

Health needs have been called the biological 
and social conditions that ensure the physiological minimum required for survival (means of life) in the sense of addressing the work force's existence and reproduction. The term "health service needs" tends to express the population's demand for health, or more accurately, for health services. But "the needs of health professionals" also exist; they refer to dentists' perceptions of the population's dental health demands. In other words, depending on the training, policy and form of remuneration by the dental service (public or private) where the professional works, the agent of this service may or may not trigger certain needs, such as the need for "extraction" rather than "prosthetics," for "restoration" rather than "preservation"; this is an important issue for research, as shown in a study regarding the British health system. ${ }^{26}$

Agents are those individuals who act on knowledge in order to attain an object of work. Knowledge is the work tool, that is to say, the tool that serves to mediate human activity over objects of work, according to the social and historical process that includes social reproduction. Thus, the working environment is the assemblage of things that the worker puts between himself/herself and the object of his/her work, and that serves to direct his/her ac- tivity in relation to that same object..$^{25}$

There is a difference between material and nonmaterial instruments. The former include equipment, instruments and materials, whereas the latter is the knowledge that coordinates material instruments within certain arrangements. These constitute the main intellectual working tools. The author emphasizes that this knowledge is also that which enables the object of his work to be attained, ${ }^{25}$ what Schraiber et al. calls "know-how." ${ }^{27}$

The work agent himself may be interpreted as a work instrument, and the immediate subject of the activity, to the extent that he/she brings to the working process both his/her previous project and its purpose, and other projects of a collective and personal nature. ${ }^{25}$

Table 2 summarizes the various objects of work, instruments and agents of work, ${ }^{25}$ taking into account the different health care models from Paim and Teixeira's ${ }^{24}$ perspective, but focusing on dentistry. The models are described only briefly; further in-depth examination in this area is required.

\section{The principal care models}

The hegemonic model has been called "privately paid medical care.” Despite the ideological nature of

Table 2 - Models of health care and oral health care, agents and working processes.

\begin{tabular}{|c|c|c|c|c|}
\hline Model & Agent & Object of work & Means of work & Forms of organization \\
\hline Private medical care model & $\begin{array}{l}\text { - Specialized } \\
\text { doctor } \\
\text { - Specialized } \\
\text { dentist }\end{array}$ & $\begin{array}{l}\text { - Diseases (pathological) } \\
\text { - Diseases (clinical and } \\
\text { surgery) }\end{array}$ & $\begin{array}{l}\text { - Medical technology } \\
\text { (individual) } \\
\text { - Dental technol- } \\
\text { ogy (implantology, } \\
\text { prosthetics, new } \\
\text { materials) }\end{array}$ & $\begin{array}{l}\text { - Network of health } \\
\text { services } \\
\text { - Hospitals } \\
\text { - In dentistry (isolated } \\
\text { practices in the dental } \\
\text { market) }\end{array}$ \\
\hline Public Health Model & $\begin{array}{l}\text { - Public health } \\
\text { doctor and aux- } \\
\text { iliaries } \\
\text { - Public health } \\
\text { dentist and aux- } \\
\text { iliaries }\end{array}$ & $\begin{array}{l}\text { - Modes of transmission } \\
\text { - Risk factors } \\
\text { - Preventive clinical or } \\
\text { individual approach to risk } \\
\text { factors }\end{array}$ & $\begin{array}{l}\text { - Public health tech- } \\
\text { nology } \\
\text { - Public health tech- } \\
\text { nology in schools }\end{array}$ & $\begin{array}{l}\text { - Public health campaigns } \\
\text { - Special programs } \\
\text { - Health fairs, lectures and } \\
\text { supervised toothbrush- } \\
\text { ing in certain settings } \\
\text { (schools and others) }\end{array}$ \\
\hline $\begin{array}{l}\text { Alternatives } \\
\text { (Health surveillance, health } \\
\text { promotion) }\end{array}$ & $\begin{array}{l}\text { - Health teams } \\
\text { - Teachers, other } \\
\text { public sectors } \\
\text { - Population } \\
\text { (citizens) }\end{array}$ & $\begin{array}{l}\text { - Harm or injuries, risks } \\
\text { - Needs, including the } \\
\text { deans of life and health } \\
\text { tions and work) }\end{array}$ & $\begin{array}{l}\text { Social communica- } \\
\text { tion, planning, local } \\
\text { situational program- } \\
\text { ming and public } \\
\text { medical health } \\
\text { technologies }\end{array}$ & $\begin{array}{l}\text { - Public health policies } \\
\text { - Intersectoral activities } \\
\text { - Specific interventions } \\
\text { (promotion, prevention } \\
\text { and recovery) } \\
\text { - Actions taken on issues } \\
\text { and population groups }\end{array}$ \\
\hline
\end{tabular}

Sources: ${ }^{25,27}$ 
its name, it is the best known and most practiced model, and is not exclusive to the private sector. Studies suggest that this model is also reproduced in the public dental sector. ${ }^{20,21,28}$ It is based on the production of procedures and broken up into specialties, involving the uncritical consumption of technology and a focus on surgical procedures in hospitals, in the case of medical practice, and on isolated practices, in the case of dentistry. It focuses on the curative aspect, and is aimed at the individual and at the biological aspects of disease; its organization is based on "free demand." This mode of organizing services reinforces the idea that only those who already have health problems will seek services, and does not include those who do not feel ill, that is to say, who do not feel the need. This compromises the comprehensiveness of care and the impact that these services will eventually have on the population's health.

In oral health, this model has been called Market Dentistry or Private Dentistry, ${ }^{29}$ although it is not restricted to the private market. As an example, one could say that traditional clinical dental practice has the objective of recovering diseased teeth through "definitive" restorations. In the case of market dentistry, caries disease is the object of work, whereas the means or instruments are the dental clinic's knowledge, and its materials are aimed at "treating" the disease. The main agent continues to be the dentist (Table 2). One of the principal criticisms here relates to an inability to regulate the individual's health needs in the private market, because capitalism reinforces inequalities to the extent that the most socially deprived individuals remain without access to dental care. This criticism was also made by Leake and $\mathrm{Birch}^{2}$ in relation to the Canadian oral health system, and there is evidence that these disparities exist in other countries. ${ }^{26,29}$

On the other hand, the public health model that initially (second half of the $19^{\text {th }}$ century) aimed at combating endemics and epidemics is characterized by the use of specific vertical campaigns and programs and is generally of an individual nature, with centralized administration and little or no coordination with other health activities. Activities are planned in order to combat epidemics, control certain diseases or explain a specific disease to the population. In an analysis of public dental health practices, we can see that many preventive practices have characteristics that can be linked to this model, featuring one-off and temporary activities, which are centrally defined. An example would be a "community-supervised tooth brushing activity." In this sense, it is possible to say that preventive care programs in schools, and the preventive practices carried out primarily by the Family Health Program (Programa de Saúde da Família) in Brazil, can now be very closely aligned with this proposition and are strongly influenced by Social and Preventive Dentistry, due to the influence of Preventive Medicine in the field of dentistry, as will be discussed briefly below. $^{21-23}$

The object of intervention in this case extends to the health of individuals. The instruments include preventive clinics, an individual approach to risk factors or common risk factors, with work instruments that include new knowledge about the prevention of oral diseases and new materials (the use of fluoride according to the "risk" classification, techniques to control bacterial plaque, glass ionomers to improve both the oral environment and occlusal sealants, periodontal risk therapy, etc.). This practice has demonstrated important advances, but its critics point out that it has produced care exclusively for groups considered to be a priority (schools and pregnant women, for example) and is unable to tackle structural issues, such as social inequalities, maintaining the focus on biological components, albeit more broadly (risk groups, common risk factors, etc.). ${ }^{21,22}$

Alternative models have advanced in line with previous models, from the perspective of overcoming the dichotomy of individual practices (private medical care model) and community practices (collective health model). They seek to incorporate a broader concept of health, by using tools from epidemiology, sociology, anthropology, political science, strategic health planning, social communication and geography. Among other things, they propose the incorporation of new agents, since they also include the organized population, in addition to health professionals and workers. Alternative 
model practices are supported beyond clinical and epidemiological determinants to include social determinants on the basis of different social groups and their living conditions. From this point on, the health surveillance model is based on interventions according to a territorial framework, working on health issues (injuries, risks and/or determinants) to offer program activities and services, including intersectoral action. ${ }^{24}$ One of the characteristics of this model is coordination between curative, promotion and prevention activities, organized on a range of care levels and working intersectorally, thus representing a great challenge. An oral health practice that includes an alternative model perspective must take into account the fact that its activities cannot be isolated from other health activities, despite its specificities. Moreover, the incorporation of health planning and programming into daily practice, as well as political-strategic analysis for the implementation of interventions and communicative action skills, are all indispensable tools for the oral health team.

It is important to clarify that it is possible to carry out collective-preventive practices of a "preventivist" nature in alternative models. What characterizes these new approaches is the expansion of the objects of work, the ways of working and the goals. These factors do not act on a group through a single mode alone. The practice of dentistry in these alternative models is still being constructed.

\section{A brief historical analysis: the origin of the movements}

Obviously, care models are produced historically, in relation to people, through social groups in conflict and in society. The discussions about the best care models to tackle the main oral health issues originate in and are closely related to the medical field. In other words, we can see that there is a clear mirroring, whereby conflicts that occur in the medical field are reflected very similarly in the dental arena.

Table 3 summarizes a series of political-ideological movements that have occurred in the medical field, their relationship with the field of dentistry and the likely impact of this "world of ideas" on professional practice, which is understood as the model.

It is worth noting that the concept of field used in this study is that offered by Bourdieu ${ }^{30}$ as an autonomous social space in which different interested agents occupy relative positions within the arena of relationships that may or may not be in conflict regarding the legitimate definition of the objects of intervention, investigation, prioritization, etc. and

Table 3 - Summary of the ideological movements and proposed care models in the medical and dental field* in the $20^{\text {th }}$ century and at the beginning of the $21^{\text {st }}$ century.

\begin{tabular}{|c|c|c|c|}
\hline \multicolumn{2}{|c|}{ Medical field } & \multicolumn{2}{|c|}{ Dental field } \\
\hline Movements & Proposed models & "Movements" & Proposed models \\
\hline Flexnerian medicine & Private medical care model & Flexnerian dentistry & Market dentistry or private dentistry \\
\hline $\begin{array}{l}\text { Traditional/government } \\
\text { public health }\end{array}$ & \multirow[t]{2}{*}{ Public health model } & Public dental health & $\begin{array}{l}\text { - Water fluoridation } \\
\text { - Incremental system }\end{array}$ \\
\hline Preventive medicine & & $\begin{array}{l}\text { - Preventive and social dentistry } \\
\text { - Simplified dentistry }\end{array}$ & $\begin{array}{l}\text { - Fluoride mouth rinse programs } \\
\text { and use of fluoride gel trays } \\
\text { - PROESA (ABOPREV) } \\
\text { - Early dental care (Baby clinics) } \\
\text { - Simplified modular clinics }\end{array}$ \\
\hline \multirow[t]{2}{*}{ Social medicine } & \multirow{2}{*}{$\begin{array}{l}\text { - Alternative models } \\
\text { - Health surveillance } \\
\text { - Welcoming approach } \\
\text { - Health promotion } \\
\text { - Healthy citizens }\end{array}$} & Comprehensive dentistry & $\begin{array}{l}\text { - Dental education } \\
\text { - Care inversion program }\end{array}$ \\
\hline & & Collective oral health & $\begin{array}{l}\text { - Family health strategy } \\
\text { - Practices being constructed }\end{array}$ \\
\hline
\end{tabular}

Sources: ${ }^{20,21,24,28,31-34}$. *"Field" in the sense of Bourdieu. ${ }^{30}$ 
specific interests. In this scenario, the dominant definition of what is legitimate and universal is exercised through the power relationship between the agents or institutions engaged in the struggle. In modern societies, the social cosmos is made up of a series of these relatively autonomous social microcosms which are fields, the settings of objective relationships. These are the arenas for the logic and specific needs of the social game, known as illusio, in other words, the agent's sense of belonging to the game for which he fights. ${ }^{30}$

In the particular case of the field of medicine, a series of ideological movements have emerged since the 1950s and 60s, which have sought to tackle the crisis identified through rising medical care costs. Traditional Public Health is not considered a movement contrary to traditional medicine, in that it emerged as an arena for government operation in cities, starting with the industrial revolution; it falls outside the free market and is considered hegemonic, although it is an arena where Flexnerian medicine prevails. ${ }^{31}$

The Public Dental Health approach has been similar to traditional public health, in which public health dentistry formulated and performed collective oral health interventions. Furthermore, this movement was the great motivator for water fluoridation systems across the world, originating in the United States and introduced in Brazil by the Foundation for Special Public Health Services (Serviços Especiais de Saúde Pública). ${ }^{20,21}$ The movement is considered a precursor to dental programming practices in Brazil. ${ }^{21,27}$ In fact, the movement reproduced practices from the surgical-restoration paradigm. Programming practices have developed through the "incremental" model, a word which incorporates the notion of gradual increments, maintaining the already-treated group and treating the group of recent arrivals, for example, at a school. It is worth noting that the focus in this case was "dental caries." It is also worth reflecting on the real contribution that programming made to this movement, where the centrality of the Finalized Treatment (FT) has remained and has been uncritically maintained in public oral health services to date. It is also worth noting that this type of care may limit access and emergency treatment in public health services, since it rejects individuals who do not have scheduled appointments. The assumption is that this clinical model is a private or market dental model and, therefore, prejudicial to greater access to dental treatment in public services. Accordingly, it must be both rethought and considered in relation to other perspectives.

The Preventive Medicine movement was specifically examined by Sergio Arouca, cited by Paim, ${ }^{32}$ in a book currently considered one of the founding works of the collective health arena in Brazil. Arouca $^{32}$ points out a "preventive dilemma," in that this movement's intention was to change medical attitudes toward medical practice, so that practice could become more "preventive" through changes to medical education. The great dilemma is that changes in attitude, without respective structural changes-such as changes to ways of paying for procedures and changes to enhance procedures carried out in hospitals-did not bring about the desired restructuring, which, in fact, did not take place.

Dentistry was also strongly influenced by this movement, as can be seen by the names of the newly created disciplines in the dental schools and the creation of Preventive Medicine Departments and Preventive and Social Dentistry Departments in the Schools of Medicine. It is curious to see this combination of the term "social" with that of "preventive" in dentistry, considering that preventive and social medicine perspectives are in opposite camps in the medical field.

Preventive and Social Dentistry, therefore, had the same aims, i.e., to change the dentist's attitude by focusing on prevention. On the other hand, in the 1980 s, the influence of the Scandinavian model was important for the dissemination of new knowledge about cariology, which scientifically legitimized a series of practices, such as supervised toothbrushing and the intensive use of fluorine. The School Dental Health Program (Programa Odontológico Escolar de Saúde), initially established by the Brazilian Association for the Promotion of Oral Health (Associação Brasileira de Promoção da Saúde Bucal), was an example of this practice and is considered a model within the Preventive Dentistry movement, 
as is that of early dental care (the Baby Clinic) with specialties. However, this is not structurally different from Preventive Medicine, since it does not seek to change the forms of remuneration, nor did it focus on incorporating any knowledge beyond clinical knowledge (Table 3).

The Comprehensive Dentistry "movement" is much more frequently seen in the arena of proposals than in structured models, and is centered on attempts to change dental education. Mendes ${ }^{33}$ indicates in his article in 1986 (the same year as the historic $8^{\text {th }}$ National Health Conference) that Comprehensive Dentistry is closer to the doctrinal principles of Health Reform. It criticizes scientific or Flexnerian dentistry and simplified dentistry, since it stresses the importance of prevention, but prioritizes cure. ${ }^{33}$ The Care Inversion Program (Programa de Inversão da Atenção) was a product of this proposal, but did not expand beyond the borders of Brazil's Southeast. This historical process regarding the different forms of dentistry has been discussed by Narvai. ${ }^{28}$

\section{Discussion}

In the case of the preventive medicine movement originating in the United States, what was at stake was the reduction of the influence wielded by social medicine, which was contrary to capitalism and had a strong Marxist influence. In terms of Preventive Medicine, the main result in Latin America was the maintenance of traditional public health, which was hegemonic, like the private medical model, but dominated by it (Table 3). In some countries, such as Brazil and Argentina, the existence of settings such as the Departments of Preventive Medicine led to the formation of a critical mass capable of giving rise to "the collective health arena" which prevails today, that is, a sphere of knowledge and practices that are not linked to the government alone. ${ }^{31}$

In this mirroring of the medical field by the dental field, one may state that the proposals and initiatives connected to the Brazilian collective health arena are frameworks that came from the European Social Medicine movements. These consider health production as an arena for the struggle for society's modes of production, and were revisited by the criti- cal health movements of Latin America.

Thus, in the arena of the oral health struggle, a movement known as Collective Oral Health, ${ }^{28}$ a preliminary concept proposed in 1988 by militant agents from the Brazilian Health Reform and concomitantly by members from the field of Dentistry-has developed a series of reflections. These represented an attempt to break from Preventive and Social Dentistry, and other forms of dentistry, and to extend the objects of practice known as oral health care, in which the oral health care model is expected to contribute to the development of its own arena of struggle, targeting Brazilian collective health.

Paraphrasing Paim ${ }^{34}$ in analyzing the Brazilian Health Reform as an idea, movement, proposal, project and process, collective health in Brazil was established as a movement of ideas (an ideological movement) and turned into a social movement that has had the potential to produce ongoing proposals, projects and processes. ${ }^{31,34}$ It is worthwhile asking what has occurred in the process of putting forth the ideology of dental agents involved in oral health and struggling with research and policy implementation versus the ideology of agents engaged in the collective health movement in Brazil.

The oral health care models adopted in a number of countries, including those that have universal public health systems, ${ }^{26}$ favor either the private medical care or the surgical-restoration model for adult care, for two reasons. ${ }^{2,26,35,36}$ The first is because, in oral health, there is a predominance of financing through private funding, direct reimbursement, private health insurance plans and even government social security. ${ }^{26}$ Consequently, free market models are not concerned a priori when acting on risks, even though this perspective may reduce injuries and increase profit margins..$^{35,36}$ Secondly, studies reveal that changes in the population's oral health profile are brought about much more frequently as the result of structural changes, such as more schooling, national wealth and socioeconomic position, than as the result of the dental practice model itself. ${ }^{13,37,38}$ In other words, the economic structure and the political superstructure that form the economic and political ideological foundations that ensure the material 
and non-material conditions required to reproduce the social structure are deemed as having a more important impact on oral health indicators and existing inequalities than the form of dental service organization. Introducing poverty reduction or direct income transfer policies, such as the Family Grant program (Bolsa Família), ${ }^{39}$ into the agenda has been crucial in reducing both social and oral health inequalities.

The great challenge is for public oral health services not to duplicate the Flexnerian model, but to broaden the perspective beyond the clinical model and oral lesions, because the way in which (clinical) dental practice is structured restricts progress in objects of intervention, thereby restricting its means and purposes. ${ }^{25}$ Moreover, since these purposes are restricted, the work instruments are also restricted, and the objects of intervention remain solely the teeth and oral diseases, in detriment to individuals, families, social groups and their ways of life.

\section{Conclusion}

The greater coverage of the public oral health service in Brazil is undeniable and is the result of a series of efforts by social movements and the Brazil-

\section{References}

1. Governo do Estado da Bahia. Secretaria de Cultura do Estado. Instituto do Patrimônio Artístico e Cultural. Aqui em sete elementos, por Bel Borba. Palacete das Artes Rodin Bahia. Salvador: Governo do Estado da Bahia; 2012. 53 p. Catálogo de exposição.

2. Leake JL, Birch S. Public policy and the market for dental services. Community Dent Oral Epidemiol. 2008 Aug;36(4):28795.

3. Müller F, Naharro M, Carlsson GE. What are the prevalence and incidence of tooth loss in the adult and elderly population in Europe?. Clin Oral Implants Res. 2007 Jun;18(3):2-14.

4. Ribeiro MT, Rosa MA, Lima RM, Vargas AM, Haddad JP, Ferreira-e-Ferreira E. Edentulism and shortened dental arch in the Brazilian elderly from the National Survey of Oral Health 2003. Rev Saude Publica. 2011 Oct;45(5):817-23.

5. Roncalli AG. National oral health survey in 2010 shows a major decrease in dental caries in Brazil. Cad Saude Publica. $2011 \mathrm{Jan} ; 27(1): 4-5$.

6. Pucca Jr GA, Costa JFR, Chagas LD, Silvestre RM. Oral Health Policies in Brazil. Braz Oral Res. 2009 Jun; 23 Suppl 1:9-16.

7. Brasil. Ministério da Saúde. Secretaria de Atenção à Saúde. Projeto SB Brasil 2010: resultados principais. [cited 2012 jul ian Health Reform. ${ }^{6,28,40}$ It is estimated that $30 \%$ of dentists in the country currently work in the Family Health Program. ${ }^{6}$ However, as Narvai stresses,${ }^{41}$ the different groups of political ideological perspectives known as "collective oral health" and "market dentistry" seek to influence the course of the National Oral Health Policy, to uphold their respective interests. One could posit that these struggles go beyond the two poles suggested, considering that even within the field of collective oral health, there are currents that are strongly connected to traditional preventive medicine practices, and that no real progress is being made regarding the collective health issue. ${ }^{41}$ In other words, the names of the disciplines and programs may have changed, but the old practices have not.

Thus, although the effect of oral health care models is of only relative importance in influencing oral health indicators, these models should not be neglected. They are arenas for an important struggle, and future scenarios will result from the several different strategies put forth by social agents interested in different political ideological movements.

02]. Available from: http://dab.saude.gov.br/cnsb/sbbrasil/index. html.

8. Narvai PC, Frazão P, Roncalli AG, Antunes JL. [Dental caries in Brazil: decline, polarization, inequity and social exclusion]. Rev Panam Salud Publica. 2006 Jun;19(6):385-93. Portuguese.

9. Cury JA, Tenuta LMA, Ribeiro CCC, Leme AFP. The importance of fluoride dentifrices to the current dental caries prevalence in Brazil. Braz Dent J. 2004 Sept-Dec;15(3):167-74.

10. Koniq J, Holtfreter B, Kocher T. Periodontal health in Europe: future trends based on treatment needs and the provision of periodontal services - position paper 1. Eur J Dent Educ. 2010 May;14 Suppl 1:4-24.

11. Hugoson A, Norderyd O. Has the prevalence of periodontitis changed during the last 30 years?. J Clin Periodontol. 2008 Sep;35(8 Suppl):338-45.

12. Carlsson GE, Omar R. The future of complete dentures in oral rehabilitation. A critical review. J Oral Rehabil. 2010 Feb;37(2):143-56.

13. Watt $\mathrm{R}$, Sheiham A. Inequalities in oral health: a review of the evidence and recommendations for action. Br Dent J. 1999 Jul;187(1):6-12. 
14. Tada A, Matsukobo T. Relationship between oral health behaviors and general health behaviors in a Japanese adult population. J Public Health Dent 2003 Fall;63(4):250-4.

15. Henriksen BM, Axéll T, Laake K. Geographic differences in tooth loss and denture-wearing among the elderly in Norway. Community Dent Oral Epidemiol. 2003 Dec;31(6):403-11.

16. Barbato PR, Nagano HCM, Zanche FN, Boing AF, Peres MA. Perdas dentárias e fatores sociais, demográficos e de serviços associados em adultos brasileiros: uma análise dos dados do estudo epidemiológico nacional (Projeto SB Brasil 2002-2003). Cad Saude Publica. 2007 Ago;23(8):1803-14.

17. Nicolau B, Thomson WM, Steele JG, Allison PJ. Life-course epidemiology: concepts and theoretical models and its relevance to chronic oral conditions. Community Dent Oral Epidemiol. 2007 Aug;35(4):241-9.

18. Sisson K1. Theoretical explanations for social inequalities in oral health. Community Dent Oral Epidemiol. 2007 Apr;35(2):81-8.

19. Tirilis D, Husson H, DeCorby K, Dobbins M. Missing and accounted for: gaps and areas of wealth in the public health review literature. BMC Public Health. 2011 Oct;11:757.

20. Oliveira AGRC, Arcieri RM, Unfer B, Costa ICC, Moraes E, Saliba NA. Modelos assistenciais em saúde bucal no Brasil: tendências e perspectivas. Ação Colet. 1999 Jan-Mar;2:9-13.

21. Nickel DA, Lima FG, Silva BB. Modelos assistenciais em saúde bucal no Brasil. Cad Saude Publica. 2008 Fev; 24(2):241-6.

22. Chaves SCL, Vieira-da-Silva LM. As práticas profissionais no campo público de atenção à saúde bucal: o caso de dois municípios da Bahia. Cien Saude Colet. 2007 NovDez;12(6):1697-710.

23. Martelli PJL, Júnior JLACA, Pimentel FC. Modelos municipais em saúde bucal: tendências atuais. Int J Dent. 2009 JulSet;8(3):146-5.

24. Paim JS, Teixeira CF. Política, planejamento e gestão: balanço do estado da arte. Rev Saude Publica. 2006 Ago; 40(n esp):73-8.

25. Schraiber LB. Ciência, trabalho e trabalhador em saúde: contribuições de Ricardo Bruno M. Gonçalves para a compreensão da articulação entre saber, práticas e recursos humanos. Divulgação Saúde Debate. 1996;14:6-17.

26. Tickle M, McDonald R, Franklin J, Aggarwal VR, Milsom K, Reeves D. Paying for the wrong kind of performance? Financial incentives and behaviour changes in National Health Service dentistry 1992-2009. Community Dent Oral Epidemiol. 2011 Oct;39(5):465-73.
27. Schraiber LB, Peduzzi M, Sala A, Nemes MIB, Castanhera ERL, Kon R. Planejamento, gestão e avaliação em saúde: identificando problemas. Cienc Saude Colet. 1999;4(2):221-61.

28. Narvai PC. Saúde bucal coletiva: caminhos da odontologia sanitária à bucalidade. Rev Saude Publica. 2006 Ago;40(n ${ }^{\circ}$ esp):141-7.

29. Drugan CS, Downer MC. [Dental health in the United Kingdom and influencing variables]. Bundesgesundheitsblatt gesundheitsforschung gesundheitsschutz. 2011 Sep;54(9):1027-34. German.

30. Bourdieu P. Le champ économique. Actes Rech Sci Soc. 1997 Sep;119:48-66.

31. Paim JS, Almeida-Filho N. Saúde coletiva: uma "nova saúde pública" ou campo aberto a novos paradigmas? Rev Saude Publica. 1998 Ago;32(4):299-316.

32. Paim JS. Medicina comunitaria: introducción a un análisis crítico. Salud Colect. 2009 Ene-Abr;5(1):121-6.

33. Mendes EV. A reforma sanitária e a educação odontológica. Cad Saude Publica. 1986 Out/Dez;2(4):533-52.

34. Paim JS. A reforma sanitária brasileira e o Sistema Único de Saúde: dialogando com hipóteses concorrentes. Physis. 2008 Nov;18(4):625-44.

35. Wallace B, MacEntee M. I Access to dental care for lowincome adults: perceptions of affordability, availability and acceptability. J Community Health. 2012 Feb;37(1):32-9.

36. Davis EE, Deinard AS, Maiga EWH. Doctor, my tooth hurts: the costs of incomplete dental care in the emergency room. J Public Health Dent. 2010 Summer;70(3):205-10.

37. Aida J, Kondo K, Kondo N, Watt RG, Sheiham A, Tsakos G. Income inequality, social capital and self-rated health and dental status in older Japanese. Soc Sci Med. 2011 Nov;73(10):1561-8.

38. Pinilla J, Gonzalez B. Exploring changes in dental workforce, dental care utilization and dental caries levels in Europe, 1990-2004. Int Dent J. 2009 Apr;59(2):87-95.

39. Brasil. Ministério da Saúde. Comissão Nacional sobre Determinantes Sociais da Saúde. As causas sociais das iniqüidades em saúde no Brasil. Rio de Janeiro: Fiocruz; 2008. [cited 2012 jul 02] Available from: http://www.cndss.fiocruz.br/pdf/home/ relatorio.pdf.

40. Paim J, Travassos C, Almeida C, Bahia L, Macinko J. The Brazilian health system: history, advances, and challenges. Lancet. 2011 May;377(9779):1778-97.

41. Narvai PC. Avanços e desafios da Política Nacional de Saúde Bucal no Brasil. Tempus. 2011 Nov;5(3):21-34. 